\title{
Güvenlik Kursu Eğitimi Alan Katılımcıların Stresle Baş Etme Tarzlarının Değerlendirilmesi
}

\author{
Ayşe Saba YALÇIN $\quad$ Behire SANÇAR $\quad$ Bayram GÖKTAŞ \\ Ankara Üniversitesi Sağllk Bilimleri Fakültesi, Ankara Türkiye \\ bgoktas@ankara.edu.tr
}

\begin{abstract}
Özet
Stres yönetimi, bireysel, kurumsal iletişim ve başarıda çok önemlidir. Hızlı yaşam koşullarının bireylerin fiziksel ve ruhsal sınırlarını zorladığı günümüzde stresin olumsuz sonuçlarının da arttığ görülmektedir. $\mathrm{Bu}$ çalışmada, mesleki ilişkilerinde stres yönetiminin bilinmesinin önemi ve gereğinden yola çıkarak, güvenlik görevlilerinin belirli bir süre eğitim aldıkları kurslar esnasında stresle baş etme tarzlarının incelenerek, uygulanan eğitim ve öğretimin bu konudaki etkisinin değerlendirilmesi amaçlanmıştır. Çalışmada, Ankara'da günde ortalama 8 saatlik programlarla 15 gün süreyle aynı içerikte dört ayrı özel güvenlik kursunda eğitim alan toplam 260 katılımcıya Folkman ve Lazarus'un (1988) geliştirdiği, Şahin ve Durak'ın (1995) kısaltarak Türkçeye uyarladıkları Stresle Başa Çıkma Tarzları Ölçeği (SBTÖ) uygulanmıştır. Betimleyici nitelikte olan araştırmada, kurs etkinlikleri esnasında katılımcıların stresle baş etme tarzlarını anlamaya yönelik görüşmeler de yapılmıştır. Sonuçta kurslar esnasında düzenlenen öğrenme yaşantılarının katılımcıların kendilerine güvenli yaklaşımlarına ve stresle baş etme tarzlarını güçlendirdiği belirlenmiştir. Farklı meslek gruplarında motivasyon ve başarının yükselmesinde stres yönetimi eğitimlerinin düzenlenmesine önem veren yeni çalışmalar planlanabilir.
\end{abstract}

Anahtar Sözcükler: Eğitim, İletişim, Stres, Stres Yönetimi, Başarı

\section{The Evaluation of Styles of Coping with Stress of the Participants Who take the Safety Course}

\begin{abstract}
Stress management is very important in individual and corporate communication and success. At the present day, when fast-living conditions force the physical and mental limits of individuals, it is seen that the negative consequences of stress also increases. In this study, based on the importance and necessity of knowing stress management in professional relations, the ways of the security officers to cope with stress during the courses in which they receive training for a particular period have been examined, and it has been aimed to evaluate the effect of the training and education that have been implemented on this issue. In the study, the Scale of Stress Coping Ways (SSCW) developed by Folkman and Lazarus (1988) and shortened and adapted to Turkish by Şahin and Durak (1995) was applied to 260 participants in total receiving training in four different private security course with an average of 8 hours of programs a day for 15 days with the same content in Ankara. In the study which is in the descriptive quality, interviews were also made aimed at understanding the ways of the participants to cope with stress during the course activities. All in all, it has been determined that the learning lives arranged during the courses strengthened the participants' self-confident approaches and their ways of coping with stress. In different
\end{abstract}


professional groups, new studies can be made giving importance to arranging stress management trainings in enhancing motivation and success can be planned.

Key Words: Training, Communication, Stress, Stress Management, Success

\section{Giriş}

Stres, organizmanın bedensel ve ruhsal sınırlarının zorlanması ve tehdit edilmesiyle ortaya çıkan bir durumdur. Diş ve iç ortamdan kaynaklanan etkenlerin organizmada yarattığı değişikliktir. (Yalçın, 2010). Stres grup içinde tartışmaların artmasına, çalışma düzeninin bozulmasına, psikosomatik belirtilerin artmasina, verimin azalmasına neden olur. Olumlu duygusal ve zihinsel tepkiler stres yönetimini ve sağlıklı iletişimi sağlar. Stresin temelinde algılama ve değerlendirme bulunmaktadır. Bireylerin olayları anlamlandırması ve yönlendirmesi stresi azaltma veya çoğaltmada temel faktördür. Aynı fiziksel ve sosyal ortam içinde bazı kimseler gergin ve stresli, bazıları ise daha rahat ve mutlu olabilir. Dolayısıyla çevre ile etkileşim, çocukluk yaşantılarında ailenin tutumu ve ekonomik düzey gibi demografik değişkenler bireylerin başa çıkma yaklaşımlarını etkilemektedir. İşlerine ve sosyal hayata daha aktif katılanlar, gelecekle ilgili olumlu beklenti içinde olanlar ve yakın çevreleri ile pozitif etkileşim içinde bulunan bireyler strese daha dayanıklı olmakta ve sağlıklı yaşamaktadırlar (Baltaş ve Baltaş, 2012).

Bireyler günlük yaşantılarında, bireysel, çevresel pek çok stres kaynağı ile karşılaşmaktadırlar. Strese anlam verme, çocukluk yaşantılarında öğrenilir. Bebeklik dönemlerinde, temel gereksinimlerin karşılandığı duygusal bağlar önce ebeveynler ile kurulmaktadır, sağlıklı gençlik ve yetişkinlik dönemlerinde varlıklarını genellikle akranlar, arkadaşlar ve karşı cinsle kurularak devam ettirmektedirler. Bağlanma stillerinin özellikle ergenliğin ortaları ve son ergenlik ve yetişkinlik yaşamını etkileyen olumlu ve olumsuz yönleri olduğu bilinmektedir. Bağlanma, özellikle ergenin kimlik arayıșı sürecinde önemli konuların başında gelmektedir. Benlik ve başkaları modelleri olumlu ve olumsuz durumlarına göre dört kategoride değerlendirilmektedir. Güvenli bağlanma stili, kişi kendisini sevilmeye değer olduğunu, başkalarının da kabul edici ve destekleyici olduğunun düşünür, ilişkilerinde güvenli ve rahattır. Saplantılı stil, olumsuz benlik modeli (değersizlik duyguları) ile olumlu başkaları modelinin (başkalarına ilişkin olumlu değerlendirmeler) birleşimiyle tanımlanır. Kayıtsız bağlanma stilinde ise, bununla zit bir yapı vardır. Son olarak korkulu stil her iki zihinsel modelinde olumsuz olduğu bir bağlanma örüntüsüne sahiptir. Dört bağlanma stilinin de iletişim becerileri üzerinde etkileri önemlidir (Sümer ve Güngör, 1999). Bağlanma ve kimlik ile ilgili kuramlar birbirinden ayrı görünmesine rağmen birçok yönde ortaklık gösterirler. Bowlby'ın (1988), bağlanma ve Erikson'un gelișim kuramlarında, kimlik tüm yaşama yayılan süreçler olarak ișlenmesine rağmen bu konudaki araştırmalar daha çok çocukluk dönemine, odaklanmıştır (Benson and Clawson, 2000).

İletişim becerisi, özellikle başkalarını anlamada onların duygu ve düşüncelerini onlarla özdeşleşerek görme duyarlığı kazanmada ve kişilerarası ilişkilerde çok önemli bir yer tutmaktadır. Bartholomew, içsel çalışan modeller kuramını (bireyin kendisi ve başkaları hakkında olumlu ya da olumsuz temsillere sahip olması), kullanarak güvenli, saplantıl1, kayıtsız ve korkulu bağlanma stillerini tanımlamıştır. Güvenli bağlanma stiline sahip bireyler hem kendilerine hem de diğerlerine ilişkin olarak olumlu bilişsel modellere sahiptir. Saplantılı bağlanmada, bireyler olumsuz benlik ve olumlu başkaları modeline sahiptirler. Kayıtsız bağlanma stiline sahip bireyler olumlu benlik ve olumsuz başkaları modeline sahiptirler. Son olarak da korkulu bağlanmada ise kendileri ve diğerleri hakkında olumsuz modellere sahiptirler (Bartholomew, 1990; Bartholomew and Horowitz, 1991).

Stres yönetiminde benlik saygısı kavramı çok önemli bir yere sahiptir. Benlik saygısı yüksek olan kişide kendine güven, iyimserlik, başarma isteği, zorluklardan yılmama gibi olumlu nitelikler bulunur. Geliştiren bir aile ortamında büyüyen çocuklar, kendine güvenen, sosyal, girişimci, sorumluluk sahibi olumlu düşünen bireyler olarak yetişirler. Bu özelliklere sahip kişilerin stresle baş etme yaklaşımları da 
yüksek olur (Yalçın, 2012). Çopur (1996) araştırmasında, ana-babanın otoriter tutumunun stresle baş etme tarzlarından çaresiz yaklaşımla anlamlı şekilde ilişkili olduğu sonucunu bulmuştur.

Stresle başa çıkma, kişinin kendini iyi hissetmesini sağlayan uygun davranışsal yaklaşımları ya da kendini kötü hissetmesini engelleyen kaçınmaları içerir. Lazarus ve Folkman, stres yönetimi stratejilerini problem çözme ve duygu odaklı olarak iki şekilde gruplandırmıştır. Problem çözme stratejisinde birey; stres durumlarını kontrol edeceğine inanarak harekete geçer, problemin çözümü şeklinde işleyen aktif bir stratejidir. Duygu odaklı baş etmede birey, durumu kontrol edemeyeceğine inanarak stres olaylarını olduğu gibi kabul ettiğinden duygu odaklı başa çıkma pasif bir strateji olarak değerlendirilmektedir (Lazarus ve Folkman,1984). Kendilerine güvenleri yeterli olmayanlar, stres karşısında, duygusal odaklı baş etme davranışı kullanırlar. Yaşanan stresli olayların sıklığ ve yoğunluğu çevre koşulları ve bireyin kişiliğinin etkileşimi ile ilgilidir (Batıgün ve Şahin, 2006). Stresin bireysel kaynakları, motivasyon ve deneyim eksikliği, bireysel hazır bulunuşluk, gelişmişlik düzeyi, hata yapma kaygısı olarak özetlenebilir.

Erdoğan (1999), stresle baş etmede bireysel olarak, etkili zaman yönetimini, rahatlama uygulamalarını, olumlu hayal kurmayı, egzersiz ve beden hareketlerini, davranışsal bakımdan kişinin kendisini kontrol etmesini ve sağlıklı iletişim kurmayı önermektedir. Yaşam tarzı değişikliği de bireylerin kullanabileceği başa çıkma yöntemlerindendir. Duygu ve düşüncelerin uygun bir şekilde ortaya konamamasında stres yaşamak kaçınılmazdır. Saldırgan bir tavırda ise bu tür davranışın yöneldiği olumsuz tepkiden dolayı stres doğal olarak yaşanır (Eren, 2001).

Kendine güvenli kişi, duygu ve düşüncelerini karşıdaki kişiye uygun şekilde yansıtır, sağglıklı iletişim kurmayı bilir. Birey stresle ilgili kişisel değerlendirmeler ve bu konudaki bilgiler ışığında, stresini kontrol edebilir. Karşıdaki kişinin duygu ve düşüncelerini anlamaya çalışmak, stresi azaltıp, olumlu düşünme gücünü attırır ve iletişimde başarıyı sağlar. Stresli durumların neden olduğu olumsuz duygular ve psikolojik uyarılmanın rahatsız edici olması, kişiyi bu durumdan kurtulmak için yeni davranışlara güdüler. Böylece bireyler, stresin kaynağını azaltarak, strese uyum gösterirler (Compas et al., 2001) Stresle başa çıkma, bireyin bilişsel ve davranışsal çabaları olarak tanımlandığında, bu davranış bireyin kişisel bilgi sürecinden geçirilerek değerlendirildiğinden bilişsel bir süreçtir ve kişinin bu kaynağın olumsuz etkisini azaltma çabasıdır (Folkman and Lazarus 1988; Özbay ve Şahin, 1997). Davison and Neale (2004) benzer olarak stresle başa çıkmayı, bireyin iç ve dış dünyasının yarattığı gereksinim ve zorlukları gidermek, onları kontrol altında tutabilmek için gösterdiği bilişsel ve davranışsal bir durum olarak açıklamışlardır. Stresle başa çıkma tarzı ne olursa olsun, dayanıklı olabilmek önemli bir niteliktir (Şahin, 1998).

Stres yönetiminde önemli olan, bireyin kendisini ve başkalarının duygularını tanıması ve anlamasının yanı sıra duygulara ilişkin bilgileri ve enerjisini günlük yaşama ve mesleğine etkin bir biçimde yansıtarak onlara uygun tepkiler göstermesi, duygusal zekâsını kullanmasıdır. Bireyler, mesleki ya da sosyal yaşamında istediği sonuçlara ulaşmak için duygularını kontrol edebilirse "duygusal zeki" olarak nitelenebilir. İyimserlik, kendine güvenli olmak, sosyal yetkinlik, stresle etkili baş etmede önemlidir. Başkalarına bağımlı, boyun eğici davranışlar gösterme, çaresizlik, stres yönetiminde etkili olmayan özelliklerdir. Dengeli ve sağlıklı ilişki kurabilen bireylerin; duygusal güvenlik içinde oldukları, olayları, durumları gerektiği biçimde yorumlayabildikleri çalıştıkları ortamlarda, başarılı oldukları bilinmektedir.

Problem çözme konusunda yeterli beceriye sahip kişiler; başarısızlıklarının nedenlerini araştıran, bu durumdan dolayı ümitsizliğe düşmeyen ve konuya ilişkin etkili faktörleri belirleyen kişilerdir. Etkili çözümler üretebilenler, sonuç ile olması gerekeni karşılaştırarak, problemlerinin çoğunu çözebileceklerine inanan, kendileri ile ilgili kararları vererek bu durumdan hoşnut olabilen, düşünen, planlı davranan, sistemli yöntem kullanan, kendine güvenli, iyimser özelliklere sahip olan bireylerdir (Altun, 2011).

Sağlkklı etkileşim verimli kurumsal iletişimin temelini oluşturur. Bireyler, sosyal ve mesleki yaşamda girdikleri çeşitli gruplar içerisinde hem kişilikleri hem de iletişimlerinden doğan pek çok stres kaynağı ile karşılaşırlar (Ekmekçi, 2007). Bireyler olumlu duyguların yararına inandıklarında, 
açık iletişim kurmakta, olumlu sosyal davranışlar geliştirmekte, stres kaynakları konusunda başarılı olmaktadırlar. Stres, çalışanların performanslarını büyük ölçüde etkiler. İş yaşamında stres, insanların mutsuz bir yaşam sürmelerine ve motivasyonlarının azalmasına neden olan etkenlerin başında gelmektedir (Örücü ve Demir, 1999). Özellikle sanayi devriminden sonra yaşanan hızlı değişim, beraberinde uyum çabasını gerektirmektedir. Bireylerden oluşan, karmaşık sosyal bir birim olan örgütlerde stres yönetimi önemli bir konudur. Günümüzün modern yönetim anlayış1 kurumların en önemli girdisi olan insana ve onun psikolojik gereksinimlerine gün geçtikçe daha fazla ilgi göstermektedir (Çakar ve Arbak, 2004). İnsanlar ve kurumlar günümüzün hızlı değişimlerine uyma gereksinimi duyduklarından karşılaştıkları güçlüklere boyun eğmek ya da direnmek arasında bir çelişki duyarak stres yönetimi konusunda zorluklar yaşamaktadırlar (Akgemci, 2001; Kaya ve Kaya, 2007). Örgütlerin amaçlarına en verimli şekilde ulaşabilmesi için çalışanlarının fiziksel ihtiyaçlarının yanında psikolojik gereksinimlerinin de karşılanması gerekmektedir (Ergül,2012). Düşük performans, bir kurumun verimini etkileyen en önemli faktörlerden biridir ve çok kere çalışanlardan kaynaklanan bir sorun olarak görülür (Atkinson et al., 1995).

Stresin neden olduğu her türlü rahatsızlık, psikolojik ve ruhsal sorunlar doğrudan bireyin motivasyonuna etki etmekte, çalışma ilişkilerine ve iş başarısına yansımaktadır (Eren Gümüştekin ve Öztemiz, 2005). Bu nedenle örgütlerde strese, stres kaynaklarına, stresle mücadele yöntemlerine, stresin sonuçlarına ve stres birey ilişkisine, iletişimde güvenli davranışın gereğine önem verilmelidir (Tokay, 2001). Çalışma yaşamında bireysel ve kurumsal başarı, stres yönetimine ilişkin eğitimlerin gereğini ortaya koymaktadır.

$\mathrm{Bu}$ çalışmada, mesleki yaşamlarında stresle baş etmenin ve iletişimlerinde kendine güvenli yaklaşımın çok önemli olduğu güvenlik görevlilerinin, belirli bir süre katıldıkları güvenlik kursları esnasında stresle baş etme yaklaşımlarının incelenerek, uygulanan eğitim ve öğretimin konuya etkisinin değerlendirilmesi amaçlanmıştır.

\section{Yöntem}

Araştırmanın amacı, mesleki ilişkilerinde stres yönetiminin bilinmesinin önemi ve gereğinden yola çıkarak, güvenlik görevlilerinin belirli bir süre eğitim aldıkları kurslar esnasında stresle baş etme tarzlarının incelenerek uygulanan eğitim ve öğretimin bu konudaki etkisinin değerlendirilmesidir. Eğitim öncesi ve eğitim sonrası alınan puanların sosyo-demografik değişkenlerle arasındaki ilişki araştırılmaktadır.

\section{Araştırmanın Evreni}

Bu çalışmada, Ankara'da günde ortalama 8'er saatlik programlarla 15 gün aynı içerikte eğitim alan dört ayrı özel güvenlik kursunda toplam 260 katılımcıya uygulama yapılmıştır. Betimleyici nitelikte olan araştırma 2013 yılı yaz döneminde temmuz-ağustos aylarında yürütülmüştür. Araştırmada evrenin tümüne ulaşılabilir olması nedeniyle ayrıca örneklem seçilmemiş̧ olup, tüm gruba uygulanmıştır. Katılımcılar çalışmaya isteyerek katılmış olup, kurs etkinlikleri başlamadan demografik bilgileri alınmış, kendilerine verilen öğrenme yaşantıları esnasında etkili iletişim ve temel ilkyardım derslerinde alanlarında uzman eğitimciler tarafından stres ve kaynakları ile baş etme yöntemlerine ilişkin eğitimler yapılmıştır.

\section{Veri Toplama Yöntemi}

Araştırmada veri toplama yöntemi olarak anket kullanılmıştır. Anket iki bölümden oluşmaktadır. Birinci bölümde güvenlik kursu katılımcılarının demografik ve kişisel bilgileri, ikinci bölümde "Stresle Başa Çıkma Tarzları Ölçeği (SBTÖ)" yer almaktadır.

Katılımcıların stresle baş etme tarzlarını değerlendirebilmek amacıyla Folkman ve Lazarus tarafından 1988 de geliştirilen Stresle Başa Çıkma Tarzları Ölçeği (SBTÖ) kullanılmıştır. Şahin ve arkadaşları(1995) tarafından Türkçeye uyarlanan ölçek, toplam 30 maddeden oluşmaktadır. Ölçeğin 
faktör analizinde "Kendine Güvenli Yaklaşım", "Çaresiz Yaklaşım”, "Boyun Eğici Yaklaşım", "İyimser Yaklaşım" ve "Sosyal Destek Arama" olmak üzere beş faktör belirlenmiştir. Cronbach alfa iç tutarlılık katsayılarının ise, iyimser yaklaşım için 0.49-0.68, kendine güvenli yaklaşım için 0.62-0.80, çaresiz yaklaşım için $0.64-0.73$, boyun eğici yaklaşım için $0.47-0.72$ ve sosyal destek arama faktörü için 0.45-0.47 arasında olduğu belirtilmiştir.

Ölçeğin puanlanmasında iki yöntem kullanılmaktadır. Çalışmanın amacına göre, etkili-etkisiz yöntemler şeklinde bir gruplama yapılacaksa; İyimser Yaklaşım, Kendine Güvenli Yaklaşım ve Sosyal Desteğe Başvurma alt boyutları toplanarak "Etkili Başa Çıkma Yöntemleri” toplam puanı, Çaresiz Yaklaşım ve Boyun Eğici Yaklaşım alt boyutları da toplanarak "Etkisiz Başa Çıkma Yöntemleri" toplam puanı elde edilmektedir. Ölçekte, her alt boyuta ait puanlar ayrı hesaplanarak, o alt boyuta ait toplam puan da elde edilebilmektedir. Alt boyutlardaki toplam puan artışı, bireyin o başa çıkma yöntemini daha çok kullandığı şeklinde yorumlanmaktadır. Alt ölçeklerden alınabilecek en düşük ve en yüksek puanlar; Kendine Güvenli Yaklaşım için 0-21 puan, İyimser Yaklaşım için 0-24 puan, Sosyal Destek Arama Yaklaşımı için 0-15 puan, Çaresiz Yaklaşım için 0-12 puan, Boyun Eğici Yaklaşım için 0-18 puandır. 1. ve 9. maddeler ters şekilde puanlanmaktadır.

Ölçeğin uyarlanması aşamasında Şahin ve Durak (1995) tarafindan yapılan üç ayrı çalışmada alt ölçeklerin güvenirlik katsayıları Kendine Güvenli Yaklaşım için $\alpha=0.62$ ile 0.80 arasında, İyimser Yaklaşım için $\alpha=0.68-0.49$ arasında, Sosyal Desteğe Başvurma için $\alpha=0.47-0.45$ arasında, Çaresiz Yaklaşım için $\alpha=0.64-0.73$ arasında, Boyun Eğici Yaklaşım için ise $\alpha=0.47-0.72$ arasında değişmiştir (Şahin ve Durak, 1995: 56-57). Tüm analizler SPSS 17.0 (SPSSFW,SPSS Inc., Chicago, USA) ile yapılmıştır.

Tanımlayıcı istatistikler için sayı, yüzde, diğerleri için puanlara ilişkin aritmetik ortalama \pm S.Sapma gösterimi kullanılmıştır. Verilerin normal dağılım ve varyansların homojen dağılım gösterip göstermediği analiz edilmiş, Kolmogorov-Smirnov testi sonucunda verilerin normal dağglım gösterdiği, Levene testi sonucunda da varyansların homojen dağılım gösterdiği saptanmıştır. Bağımsız gruplar arasında farklılı̆̆ın istatistiksel açıdan anlamlı olup olmadığını belirlemek için iki faktörlü varyans analizi tekniği kullanılmıştır. Bağımlı iki grubun karşılaştırılması için "Paired Samples t Testi” uygulanmıştır. Tüm analizler için yanılma düzeyi olarak $\alpha=0.05$ seçilmiştir. Bu değerden büyük p değerleri istatistiksel olarak önemsiz, küçük ya da eşit p değerleri ise anlamlı şeklinde yorumlanmıştır.

\section{Bulgular}

Araştırmada toplanan veriler analiz edildikten sonra ortaya çıkan tanımlayıcı bulgular Tablo 1'de verilmektedir.

Tablo 1. Araştırma Grubunun Sosyo-Demografik Özelliklerine Göre Dağılımı (n: 260)

\begin{tabular}{|clcc|}
\hline Sosyo-Demografik Özellikler & Sayı & $\%$ \\
\hline \multirow{2}{*}{ Yaş } & 21 Yaş ve altı & 60 & 23,1 \\
$26,41 \pm 7,06$ & $22-25$ & 93 & 35,8 \\
& $26-29$ & 43 & 16,5 \\
\multirow{2}{*}{ Cinsiyet } & 30 Yaş ve üzeri & 64 & 24,6 \\
& Erkek & 171 & 65,8 \\
\multirow{3}{*}{ Medeni Durum } & Kadın & 89 & 34,2 \\
& Evli & 65 & 25,0 \\
& Bekâr & 191 & 73,5 \\
& Dul/Boşanmış & 4 & 1,5 \\
Eğitim Düzeyi & İlkokul & 4 & 1,5 \\
& Ortaokul & 75 & 28,8 \\
& Lise & 155 & 59,6 \\
& Üniversite & 26 & 10,0
\end{tabular}




\begin{tabular}{|clcc|} 
& 2 ve altı & 28 & 10,8 \\
Evde Yaşayan Birey & 3 & 81 & 31,2 \\
& 4 & 83 & 31,9 \\
& 5 & 42 & 16,2 \\
Sosyal Güvence & 6 ve üzeri & 26 & 10,0 \\
& Var & 156 & 60,0 \\
& Yok & 104 & 40,0 \\
\hline
\end{tabular}

Araştırma grubunun sosyo-demografik özelliklere göre dağılımı incelendiğinde \%35'inin 22-25 yaş aralı̆̆ında olduğu, \%65,8'inin erkek olduğu, \%73,5'inin bekâr olduğu, \%59,6'sının lise mezunu ve $\%$ 60,0'1nın sosyal güvenceye sahip olduğu görülmektedir (Tablo:1).

Kurs katılımcılarının, stresle baş etme tarzları ölçeğinden aldıkları öntest ve sontest puanlarının dağılımı incelendiğinde (Tablo:2), puanlar arasında anlamlı bir farklılık olduğu saptanmıştır $(p<0,005)$.

Tablo 2. Araştırma Grubunun Stresle Baş Etme Tarzları Ölçeğine İlişkin Öntest ve Sontest Puanlarının Dağılımı

\begin{tabular}{|c|c|c|}
\hline Stresle Baş Etme Tarzları & Ortalama \pm Standart Sapma & $\mathbf{p}$ \\
\hline Eğitim Öncesi Kendine Güvenli Yaklaşım & $15,79 \pm 3,87$ & \multirow{2}{*}{$-2,852,005$} \\
\hline Eğitim Sonrası Kendine Güvenli Yaklaşım & $16,62 \pm 3,71$ & \\
\hline Eğitim Öncesi İyimser Yaklaşım & $10,01 \pm 3,05$ & \multirow{2}{*}{$-2,790,006$} \\
\hline Ĕ̆itim Sonrası İyimser Yaklaşım & $10,52 \pm 2,63$ & \\
\hline Ĕgitim Öncesi Çaresiz Yaklaşım & $10,23 \pm 4,28$ & \multirow{2}{*}{$5,005,000$} \\
\hline Eğitim Sonrası Çaresiz Yaklaşım & $8,79 \pm 4,12$ & \\
\hline Eğitim Öncesi Boyun Eğici Yaklaşım & $5,34 \pm 3,47$ & \multirow{2}{*}{$4,381, \mathbf{0 0 0}$} \\
\hline Eğitim Sonrası Boyun Eğici Yaklaşım & $4,25 \pm 3,25$ & \\
\hline Eğitim Öncesi Sosyal Destek Arama Yaklaşımı & $6,91 \pm 1,99$ & \multirow{2}{*}{$-6,700,000$} \\
\hline Eğitim Sonrası Sosyal Destek Arama Yaklaşımı & $8,19 \pm 3,11$ & \\
\hline Eğitim Öncesi Stresle Başa Çıkma Tarzları Ölçeği (SBTÖ) & $46,83 \pm 7,82$ & \multirow{2}{*}{$-3,164,002$} \\
\hline Eğitim Sonrası Stresle Başa Çıkma Tarzları Ölçeği (SBTÖ) & $48,38 \pm 6,76$ & \\
\hline
\end{tabular}

Tablo 2'de görüldüğü gibi, kendine güvenli yaklaşım puan ortalamas1 eğitimden önce $15,78 \pm 3,87$ iken eğitim sonrasında $16,62 \pm 3,71$ olarak bulunmuştur $(\mathrm{p}<0,005$ ). İyimser yaklaşım puan ortalaması $10,01 \pm 3,05$ iken eğitim sonrasında 10,52 $\pm 2,63$ olarak saptanmıştır $(p<0,005)$.

Çaresiz yaklaşım puan ortalaması $10,23 \pm 4,28$ iken eğitim sonrasında $8,79 \pm 4,12$ olarak bulunmuştur $(\mathrm{p}<0,005)$. Boyun eğici yaklaşım puan ortalaması 5,34 $\pm 3,47$ iken eğitim sonrasında $4,25 \pm 3,25$ olarak saptanmıştır $(p<0,005)$. Sosyal destek arama yaklaşımı puan ortalaması $6,91 \pm 1,99$ iken eğitim sonrasında $8,19 \pm 3,11$ olarak saptanmıştır ( $\mathrm{p}<0,005)$. Eğitim öncesi stresle başa çıkma tarzları ölçeği (SBTÖ) puan

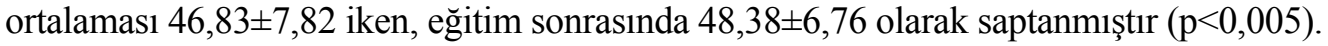

Tablo 3. Araştırma Grubunun Eğitim Durumlarına Göre Çaresiz Yaklaşıma İlişkin Öntest ve Sontest Puanlarının Dağılımı

\begin{tabular}{|c|c|c|c|c|c|c|c|}
\hline \multirow{2}{*}{ Eğitim düzeyi } & \multirow{2}{*}{$\mathrm{N}$} & \multicolumn{4}{|c|}{ Çaresiz Yaklaşım Eğitim Öncesi Çaresiz Yaklaşım Eğitim Sonrası } & \multirow{2}{*}{$\mathrm{F}$} & \multirow{2}{*}{$\mathrm{p}$} \\
\hline & & Ortalama & Standart Sapma & Ortalama & Standart Sapma & & \\
\hline İlkokul & 4 & 15,00 & 3,55 & 7,00 & 2,44 & & \\
\hline Ortaokul & 75 & 10,92 & 3,89 & 8,77 & 4,36 & & \\
\hline Lise & 155 & 9,74 & 4,26 & 8,54 & 3,87 & 4,610 & ,004 \\
\hline Üniversite & 26 & 10,38 & 4,98 & 10,53 & 4,74 & & \\
\hline Toplam & 260 & 10,22 & 4,28 & 8,78 & 4,12 & & \\
\hline
\end{tabular}



DEĞERLENDİRILMESİ

Yapılan ilişkili ölçümler için iki faktörlü varyans analizi yapılmış, sonucunda güvenlik kursu programı öncesi ve sonrasında alınan puanlar, kursta verilen eğitimin program sonrası ilkokul, ortaokul ve lise düzeylerinde stres yönetiminde çaresizlik yaklaşımının etkili olmadığının anlaşılması konusunda anlamlı bir farklılık olduğunu göstermektedir (Tablo: 3 ). Üniversite düzeyinde ise etkili başa çıkma yöntemlerinin program öncesi bilindiği ve bu konuda davranışların biraz artarak, devam ettiği görülmüştür.

Yapılan istatistik analizlerde; katılımcıların yaş değişkenleri ile stresle baş etme bakımından kurs sonrası puanlarının dağılımında anlamlı bir farklılık görülmemiştir (Tablo 4).

Tablo 4. Araştırma Grubunun Yaşlarına Göre Stresle Başa Çıkma Tarzları Ölçeğine İlişkin Öntest ve Sontest Puanlarının Dăğlımı

\begin{tabular}{|c|c|c|c|c|c|c|}
\hline \multirow{2}{*}{ Yaş } & \multirow{2}{*}{$\mathrm{N}$} & \multicolumn{2}{|c|}{$\begin{array}{l}\text { Stresle Başa Çıkma Tarzları Ölçeği } \\
\text { (SBTÖ) Eğitim Öncesi }\end{array}$} & \multicolumn{2}{|c|}{$\begin{array}{l}\text { Stresle Başa Çıkma Tarzları Ölçeği } \\
\text { (SBTÖ) Eğitim Sonrası }\end{array}$} & \multirow{2}{*}{$\mathrm{p}$} \\
\hline & & Ortalama & Standart Sapma & Ortalama & Standart Sapma & \\
\hline 21 yaş altı & 60 & 45,30 & 7,28 & 46,58 & 7,11 & \multirow{5}{*}{$\begin{array}{cc}0,9 & 0,402 \\
81 & 0,40\end{array}$} \\
\hline $22-25$ & 93 & 46,83 & 6,44 & 49,01 & 6,19 & \\
\hline $26-29$ & 43 & 46,44 & 6,50 & 48,93 & 7,67 & \\
\hline 30 yaş ve üzeri & 64 & 48,50 & 10,36 & 48,76 & 6,42 & \\
\hline Toplam & 260 & 46,82 & 7,81 & 48,37 & 6,75 & \\
\hline
\end{tabular}

\section{Tartışma ve Sonuç}

Yaşamın bir parçası olan stres, her zaman vardır, iyi yönetildiğinde çalışmalara destek olur, bireye güç verir. Önemli olan stres yönetimini bilmek, tükenme evresine geçmeden baş etme yöntemlerini kullanabilmektir. Çalışanların stres kaynaklarının belirlenerek, bu konuda bilinçlenmeleri motivasyon ve başarılarının artmasında çok önemlidir (Yalçın, 2010 ).

Çalışma sonucunda, kursun başlangıcına göre özel güvenlik eğitimi katılımcılarının genel olarak, kendine güvenli ve iyimserlik yaklaşımlarında artış, çaresizlik, boyun eğme, yaklaşımlarında düşme olduğu gözlenmiştir. Sosyal destek arama puanlarındaki yükselme, program tamamlandığında duygusal zekâ boyutlarından başkalarını etkili dinleme ve anlama becerilerinin artmış olması ile bu konuya duyulan gereksinim ile açıklanabilir.

Demografik değişkenlerden sadece katılımcıların eğitim düzeyleri ile stresle baş etme tarzlarından çaresiz yaklaşım arasında anlamlı bir farklılık gözlenmiştir. Erkmen ve Çetin (2008),beden eğitimi öğretmenlerinin stresle başa çıkma tarzlarının bazı değişkenlerle ilişkisini inceledikleri araştırmalarında stresle başa çıkma tutumları açısından evli ve çocuk sahibi olan öğretmenlerin, stresle başa çıkma tutumları konusunda daha başarılı oldukları sonucu bulunmuştur. Yaş değişkenine göre stresle başa çıkma tarzları arasında anlamlı bir farklılaşmanın bulunmadığı sonucunu destekleyen başka çalışmalar bulunmaktadır (Çağlayan ve ark, 2010; Yurtsever, 2009). Lopez et al. (2001) tarafindan yapılan araştırmada, cinsiyetin stresle başa çıkma tarzları üzerinde bir farklılık oluşturmadığı sonucuna varılmıştır. Tıp Fakültesi ve Sağlık Yüksekokulu öğrencilerinde depresif belirti yaygınlığı, stresle başa çıkma tarzlarını etkileyen faktörlerin incelendiği çalışmada, Tıp Fakültesinde ailesinin aylık gelir düzeyi asgari ücret ve altında olanlarda depresif belirtiler, stresle başa çıkma tarzları ile ilişkili ruhsal sorunlar yüksek bulunmuştur (Kaya, Genç, Kaya ve Pehlivan, 2007).

Adölesanlarda beslenme ile stres yönetimi konularında verilen eğitimin bu konuya etkisinin incelendiği çalışmada, ergenlerin beslenmeye yönelik sağlık davranışlarında ve stres yönetimine ilişkin becerilerinde eğitim, öğretim yaşantıları sonunda, bir artış olduğu gözlenmiştir (Geçkil ve Y1ld1z, 2006). 
Kurs katılımcılarının, program öncesi ve sonrası çaresizlik yaklaşım puanları arasında görülen anlamlı farklılık, çalışmalar esnasında verilen dersler ve drama çalışmalarında, duygusal zekâ ile stres yönetimine ilişkin bilgi ve becerilerin bireylerin stresle başetme tarzlarına katkıda bulunmasına ve kendilerine güvenlerinin artmış olmasına bağlanabilir. Eğitim düzeyi yükseldikçe, bireylerin stres yönetiminin yaşamdaki öneminin bilincine varmalarına, çaresizliğin sorunları çözmedeki yetersizliğinin, problem çözme odaklı stratejilerin öneminin anlaşılması ile açılanabilir. Program sonrası, katılımcıların kendine güven ve iyimserlik yaklaşımı puanlarının yükselmiş olması, bu özelliklerin stres yönetimi konusunda problem çözücü rolünün kazanılmış olabileceğini göstermektedir.

Konuyla ilgili yapılan araştırmalar, duygu odaklı başa çıkma stratejisinin, problem odaklı başa çıma stratejisine göre daha az etkili olduğunu ve daha çok psikolojik belirtilere eşlik ettiğini göstermektedir (Billings and Moos, 1984; Sigmon, Stanton and Snyder, 1995). Aydin (2008) araştırmasında, farklı problem çözme ve sosyal destek stratejileri düzeyine sahip olan ergenlerin, kişisel, sosyal ve genel uyum düzeyleri arasında bir farklılaşma bulunmazken, farklı kaçınma strateji düzeylerine sahip olanların kişisel, sosyal ve genel uyum düzeyleri arasında önemli farklılıklar bulunmuştur. Lise öğrencilerinin mizah tarzları ve stresle başa çıkma tarzları arasındaki ilişkinin incelendiği çalışmada, kendini geliştirici mizah tarzına yüksek düzeyde sahip olan öğrencilerin düşük düzeyde sahip olan öğrencilere oranla 'kendine güvenli yaklaşım' ve 'iyimser yaklaşım' tarzlarına daha çok, 'çaresiz' ve 'boyun eğici yaklaşım' tarzlarına ise daha az başvurdukları görülmüştür. Eğitim yaşantılarının bu konuda bireylere yardımcı olduğu gösterilmiştir (Yerlikaya, 2007).

Çalışmalara istekle katılmanın, kendine güvenmede, kararlılık da, önemi vardır. Güvenlik kursuna katılanların, istek duyarak çalışmalara başlamış olmaları, stres eğitimlerinin istenilir sonuca ulaşmasında katkı sağlamış olabilir. Benzer olarak, Temel, Bahar ve Çuhadar (2007), Sağlık Yüksekokulu öğrencilerinin stresle baş etme tarzları ile depresyon düzeyleri arasındaki ilişkiyi incelediği araştırmalarında, hemşirelik mesleğini başarıyla sürdürebileceğine inanan, isteyerek tercih eden öğrencilerin kendine güvenli ve iyimser yaklaşım puanları anlamlı derecede yüksek bulunmuştur.

Stresle mücadelede, kuruma düsen en önemli görev, bu konudaki bilgiler 1şığında, çalışanların kendilerini tanımalarına ve tanımlamalarına yardımcı olmasıdır. Stres kaynaklarının kurum ve bireyler tarafından bilinmesi, bu konuda önlem alınmasının ilk adımı olacaktır. Strese ilişkin tepkiler konusunda bireyin dayanma gücü, kalıtımsal yapısı, gelişimsel özellikleri, olay karşısındaki deneyimleri ve daha birçok etken nedeniyle bireysel farklılıklar vardır (Öztürk, 2002). Kaynakların çok çeşitli olması, her bireyde farklı yaşanması bu konudaki çalışmaların sonuçlarının değerlendirilmesini güçleştirmektedir. Örgütlerde, öneriler ve çözümlerle stresin olumlu gelişmeler yaratabileceği bir düzenin kurulması yararlıdır. Stres yönetimi ile motivasyondaki olumlu etkiler desteklenir, olumsuz olanlar azaltılmaya ve yok edilmeye çalışılır (Connor and Worley, 1991). Örgütsel stres yönetimi, bireylerde ve gruplarda oluşan stresle ilgili ruhsal ve davranışsal sorunları önlemek ve azaltmak için çalışmaktadır.

Yapılacak çalışmalarda, çalışma ortamlarında, stresi arttıran faktörlerin belirlenip, bunları azaltma yönünde çabalar gösterilmesi, motivasyon ve başarı bakımından önemlidir. Yeni kurs etkinliklerinde katılımcıların, daha başarılı ve mutlu olabilmeleri için, stresle baş etme davranışlarının planlı eğitimler yoluyla geliştirilmesine önem verilmelidir. Örgütler, başlangıç ve gelişme aşamasında önleyici hizmet verme yoluyla stresle mücadele yapmak durumundadır. Bu konuda, katılımcılar küçük gruplara ayrılarak, kendilerini daha rahat hissedebilecekleri, uzun süren, etkili iletişim ve problem çözme becerilerini kullanabilecekleri programlar, stres yönetimi eğitimleri düzenlenebilir. Bu etkinlikler yolu ile bireylerin kendilerini gerçekleştirmelerine ve eğitimde başarının arttırılmasına katkıda bulunulabilir. 


\section{Kaynakça}

Akgemci, T. 2001. Örgütlerde Stres ve Yönetimi. Atatürk Üniversitesi İktisadi ve İdari Bilimler Fakültesi Dergisi, 15 (1-2), 301-310.

Altun, A. S. 2011. Başarılı İlköğretim Okulu Müdürlerinin Zaman Yönetimi Stratejileri. Educational Administration: Theoryand Practice, 17 (4), 491-507.

Atkinson, R.L., R.C. Atkinson \& E. R. Hilgard. 1995. Psikolojiye Giriş II. Çev. Kemal Atakay. Mustafa Atakay ve Aysun Yavuz., Sosyal Yayınlar, İstanbul,.

Aydın, H. 2008. Ergenlerin Kişilik Özelliklerinin Stresle Başa Çıkma ve Bazı Özlük Niteliklerine Göre, Karşılaştırmalı Olarak İncelenmesi. Yüksek Lisans Tezi, Selçuk Üniversitesi.

Baltaş, A.ve Baltaş, Z. 2012. Stres ve Başa Çıkma Yolları. İstanbul: Remzi Kitabevi.

Blehar, M. C., Waters. E. \& Wall, S. 1978. Patterns of attachment: A Psychological study of the strange situation, Hillsdale. N J: Earlbaum.

Bartholomew, K. 1990. Avoidance of intimacy: An attachment perspective. Journal of Social and Personal Relationship, 7, 147-178.

Bartholomew, K \& Horowitz, L. M. 1991. Attachment styles among young adults: A test of a four category model. Journal of Personality and Social Psychology, 61, 226-244.

Batıgün Durak, A. ve Şahin, H. N. 2006. İş Stresi ve Sağlık Psikolojisi Araştırmaları için İki Ölçek: A Tipi Kişilik ve İş Doyumu. Türk Psikiyatri Dergisi, 17(1), 32-45.

Benson, D.R. \& Clawson, M. L. 2000. Evolution of the actinorhizal plantsymbioses in triplett, E.W. (Ed.), prokaryotic nitrogen Fixation: a model system for analysis of biological process. Horizon scientific press, wymondham, UK, 207-224.

Bilen, M. 1994. Sağlıklı Insan İlişkileri. Ankara: Armoni Yayıncılık.

Billings, A. G. \& Moos, R. H. 1984. Coping, stress, and social resources among adults with unipolar depression. Journal of Personality and Social Psychology, 46, 877-891.

Bowlby, J. 1988. A secure base: parent-child attachment and healthy human development. New York: Books.

Compas, B. E., Connor-Smith, J., Joltzman, H., Thompson, A. H. \& Watsvorth, M. 2001. Stres during Childhood and adollescence: Problems, progress and potential in the oryand research. Psychological Bullletin, 127 (1), 87-127.

Connor, P.E. \& Worley, C. H. 1991. Managing Organizational Stres. Business Quarterly, 56 (1), 61-63.

Çakar, U. ve Arbak, Y. 2004. Modern Yaklaşımlar Işı̆̆ıında Değişen Duygu-Zekâ İlişsisi ve Duygusal Zekâ. Dokuz Eylül Üniversitesi Sosyal Bilimler Enstitüsü Dergisi, 6 (3), 23-48.

Çağlayan, H.S., Çetin, M.Ç., Yıldırım, Y. ve Yıldız, Ö. 2010. Investigation of Coping with the stress styles of physical education and sport school special ability test participating candidates. 11th International sport sciences congress. November 10-12, presentations. Antalya/Turkey. 58-60.

Çopur, F. 1996. Ana-Baba Tutum Algısının Kız Öğrencilerin Kullandıkları Stresle Başa Çıkma Yollarına Etkisi. Yüksek Lisans Tezi, Çukurova Üniversitesi.

Davison, G. C. \& Neale, J. M. 2004. Anormal Psikoloji. (Çev. Edt. İhsan Dağ) Anormal psikolojisi. Türk Psikologlar Derneği Yayınları, Ankara.

Ekmekçi, R. 2007. Basketbol Hakemlerinin Stres Kaynaklarl ve Stresle Başa Çıkma Yöntemlerinin Tespiti ve Önleyici Yönetsel Uygulamaların Geliştirilmesi. Doktora tezi, Bolu Abant İzzet Baysal Üniversitesi.

Erdoğan, İ. 1999. İşletme Yönetiminde Örgütsel Davranış. İstanbul: Dönence Basım ve Yayın Hizmetleri.

Eren, M. E. 2001. İstanbul Emniyet Müdürlüğü Tem Şube Müdürlüğü Personelinin Stres Kaynakları Belirtileri ve Stresle Başa Çıkma Yöntemleri. Yüksek Lisans Tezi, Yıldız Teknik Üniversitesi.

Eren Gümüştekin, G. ve Öztemiz, A. B. 2005. Örgütlerde Stresin Verimlilik ve Performansla Etkileşimi. Çukurova Üniversitesi Sosyal Bilimler Enstitüsü Dergisi, 14 (1), 271-288. 
Ergül, A. 2012. Çalışma Yaşamında Stresin Bireysel Performans Üzerindeki Etkileri. Eğitim ve Sağlık Çalışanlarına Yönelik Bir Araştırma. Yüksek Lisans Tezi, Balıkesir Üniversitesi.

Erkmen, N. ve Çetin, Ç. M. 2008. Beden Eğitimi Öğretmenlerinin Stresle Başa Çıkma Tarzlarının Bazı Değişkenlerle İlişkisi. Selçuk Üniversitesi Sosyal Bilimler Enstitüsü Dergisi, 39 (19), 231-242.

Folkman, S. \& Lazarus, R. S. 1988. Coping as a mediator of emotion. Journal of Personality and Social Psychology, 54, 466-475.

Geçkil, E. ve Yıldız, S. 2006. Adölesanlara Yönelik Beslenme ve Stresle Baş Etme Eğitiminin Sağlığ Geliştirmeye Etkisi. C.Ü. Hemşirelik Yüksek Okulu Dergisi, 10 (2), 19-28.

Kaya, A. ve Kaya Y. 2007. Küçük ve Orta Boy İşletme Yöneticilerinin Stres Kaynaklarını Tespit Etmeye Yönelik Kayseri İlinde Bir Araştırma. Erciyes Üniversitesi, Sosyal Bilimler Enstitüsü Dergisi, 23 (2), 41-62.

Kaya, M., Genç, M., Kaya, B. ve Pehlivan, E. 2007. Tıp Fakültesi ve Sağlık Yüksekokulu Öğrencilerinde Depresif Belirti Yaygınlığı. Stresle Başa Çıkma Tarzları ve Etkileyen Faktörler Türk Psikiyatri Dergisi, 18(2), 137-146.

Lazarus, R.S. \& Cohen, J.B. 1977. Environmental stress. In I. Altmanand J.F. Wohlwill (eds.), Human Behavior and Environment. (Vol 2) New York: Plenum.

Lazarus R., Folkman, S. 1984. Stress, appraisal and coping. Newyork: Springer Press. 142.

Lopez, F.G., Mauricio, A.M., Gormley, B., Simko, T., \& Berger, E. 2001. Adult attachment orientations and college student distress: The mediating role of problem coping styles. Journal of Counselingand Development, 79 (4), 459- 464.

Özbay, Y. ve Şahin, B. 1997. Stresle Başa Çıkma Tutumları Envanteri: Geçerlik ve Güvenirlik Çalışması. IV. Ulusal Psikolojik Danışma ve Rehberlik Kongresinde Sunulmuş Bildiri, Ankara.

Örücü, E. ve Demir B. 1999, Banka Çalışanlarında İş Stresi ve Muğla İli Örneği, Atatürk Üniversitesi İktisadi ve Idari Bilimler Fakültesi Dergisi, 13 (1), 2-10.

Öztürk, O. 2002. Ruh Sağlı̆̆ ve Bozuklukları. Ankara: Nobel Tıp Kitabevi.

Sümer, N. ve Güngör, D. 1999. Psychometri cassessment of adult attachment styles and cross- cultural comparison of scales on which theTurkish sample. Turkish Journal of Psychology, 14 (43), 35-62.

Sigmon, S.T., Stanton, A. L. \& Snyder, C. R. 1995. Gender differences in coping: A further test of socialization and role constraint theories. Sex Roles, 33, 565-587.

Şahin, N.H. 1998. Stresle Başa Çıkma: Olumlu Bir Yaklaşım. 3. Basım, Ankara: Türk Psikologlar Derneği Yayınlar1.

Temel, E., Bahar, A. ve Çuhadar, D. 2007. Öğrenci Hemşirelerin Stresle Baş Etme Tarzları Depresyon Düzeylerinin Belirlenmesi. Fırat Sağllk Hizmetleri Dergisi, 2, (5),108-118.

Yalçın, S. 2010. Mutluluk İçin Pozitif Düşünme. Songür Yayıncılık, Ankara.

Tokay, T. 2001. Örgütsel Stres ve Performans İlişkisi. Yüksek Lisans Tezi, Gazi Üniversitesi.

Yalçın, S. 2012. Psikoloji. Songür Yayıncılık, Ankara.

Yerlikaya, N. 2007. Lise Öğrencilerinin Mizah Tarzları İle Stresle Başa Çıkma Tarzları Arasındaki İlişkinin İncelenmesi. Yüksek Lisans Tezi, Çukurova Üniversitesi.

Yurtsever, H. 2009.Kişilik Özelliklerinin Stres Düzeyine Etkisi ve Stresle Başa Çıkma Yolları: Üniversite Öğrencileri Üzerine Bir Araştırma. Yüksek Lisans Tezi, Dokuz Eylül Üniversitesi. 